\title{
Pengaruh Keragaman Gender Dewan, Industri dan Ukuran Perusahaan terhadap Donasi Corporate Social Responsibility
}

\author{
Dwi Ayu Indriyani ${ }^{1}$ \\ Fakultas Ekonomi dan Bisnis \\ Universitas Airlangga, Indonesia
}

\author{
Erina Sudaryati ${ }^{2}$ \\ Fakultas Ekonomi dan Bisnis \\ Universitas Airlangga, Indonesia
}

\begin{abstract}
Surel : dwiayuindryn@gmail.com
ABSTRAK

Perkembangan bisnis yang mengikuti konsep triple bottom line (TBL) mendorong perusahaan untuk memperhatikan permasalahan lingkungan dan sosial bukan hanya fokus pada profit yang dihasilkan. Perusahaan harus bisa berkontribusi dengan memberikan donasi dalam kegiatan corporate social responsibility atau dikenal dengan istilah corporate philanthropy sebagai bentuk pertanggungjawaban pada pihak stakeholder. Penelitian berfokus pada faktor keragaman gender dewan, jenis industri dan ukuran perusahaan terhadap donasi CSR. Penelitian ini menggunakan metode regresi berganda. Sampel penelitian menggunakan perusahaan yang terdaftar di bursa efek Indonesia periode 2017-2018. Hasil penelitian menunjukkan bahwa keragaman gender dewan dan jenis industri berpengaruh signifikan terhadap donasi CSR, sedangkan ukuran perusahaan tidak berpengaruh signifikan.
\end{abstract}

Kata Kunci: Keragaman Gender Dewan; Ukuran Perusahaan; Jenis Industri; Donasi Corporate Social Responsibility.

\section{Effect Of Board Gender Diversity, Industry and Company Size On Corporate Social Responsibility Donations}

\section{ABSTRACT}

Business developments that embrace the concept of a triple bottom line (TBL) encourage companies to pay attention to environmental and social challenges rather than just focus on maximum profits. Companies must contribute by making donations in corporate social responsibility activities or known as corporate philanthropy as a form of accountability to stakeholders. Research on the factor of board gender diversity, industry type and company size on CSR donations. This research uses multiple regression method. The research sample uses companies listed on the Indonesia stock exchange period 2017-2018. The results showed that the board gender diversity and the type of industry had a significant effect on CSR donations, while the size of the company had no significant effect.

Keywords: $\quad$ Board Gender Diversity; Firm Size; Industry Type; Donation On Corporate Social Responsibility.

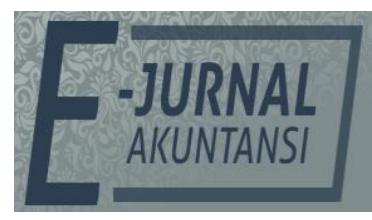

e-ISSN 2302-8556

Vol. 30 No. 8

Denpasar, Agustus 2020

Hal. 2009-2024

DOI:

10.24843/EJA.2020.v30.i08.p09

PENGUTIPAN:

Indriyani, D. A. \& Sudaryati, E. (2020). Pengaruh

Keragaman Gender Dewan, Industri dan Ukuran

Perusahaan terhadap Donasi Corporate Social Responsibility.

E-Jurnal Akuntansi, 30(8),

2009- 2024

RIWAYAT ARTIKEL:

Artikel Masuk:

17 Juni 2020

Artikel Diterima:

4 Agustus 2020

Artikel dapat diakses : https://ojs.unud.ac.id/index.php/Akuntansi/index 


\section{PENDAHULUAN}

Arah perkembangan bisnis semakin bergerak pesat sehingga mendorong perusahaan untuk tidak hanya berorientasi pada profit yang maksimal saja. Konsep triple bottom line (TBL) yang meliputi people, planet, dan profit menjadi faktor pendorong perusahaan untuk memperhatikan aspek lingkungan dan sosial. Perusahaan harus bisa bertanggung jawab pada stakeholder, masyarakat, konsumen, pemerintah dan pihak lainnya. Beberapa dekade terakhir menunjukkan bahwa stakeholder dan masyarakat semakin menyadari pentingnya tanggung jawab sosial perusahaan (Houqe et al., 2019). Bentuk tanggung jawab sosial yang dilakukan oleh perusahaan biasanya berupa donasi. Donasi dalam melakukan corporate social responsibility dikenal dengan istilah corporate philanthropy, merupakan bagian penting dari perusahaan saat melakukan tanggung jawab sosialnya (Abebe \& Cha, 2018). Penelitian mengenai donasi atau corporate philanthropy masih jarang dilakukan, khususnya di Indonesia. Penelitian serupa lebih banyak berfokus pada laporan corporate social responsibility saja. Padahal penting untuk diteliti lebih dalam mengenai besarnya nominal donasi yang di laporkan oleh perusahaan sebagai pertanggungjawaban sosial.

Donasi yang diberikan perusahaan atau corporate philanthropy berupa kontribusi moneter yang ditujukan sebagai bantuan sosial dan amal meliputi pendidikan, budaya, perawatan kesehatan, bantuan bencana alam, pemberian donasi pada panti asuhan, pemberian dan hibah untuk usaha pertanian maupun peternakan, beasiswa, pelatihan kewirausahaan, maupun donasi untuk memberikan peralatan yang digunakan untuk peningkatan keahlian (Gao et al., 2016). Upaya pemberian donasi juga bertujuan untuk mengurangi banyaknya permasalahan yang terjadi akibat kegiatan operasional perusahaan maupun adanya bencana alam menjadi aspek yang terus diperhatikan perusahaan sebagai sasaran untuk melakukan tanggung jawab sosialnya. Donasi atau pemberian yang dilakukan perusahaan menjadi isu startegis utama bagi perusahaan, hal ini dikarenakan perusahaan semakin memposisikan diri sebagai organisasi yang bertanggung jawab secara sosial (Gardberg et al., 2017).

Corporate philanthropy merupakan bentuk khusus serta sarana yang penting bagi perusahaan untuk memenuhi tanggung jawab sosial sehingga bisa memberikan kontribusi positif untuk kinerja perusahaan secara menyeluruh (Cha \& Abebe, 2016) dan (Wu et al., 2018). Peran strategis dari pemberian donasi sebagai bentuk tanggung jawab sosial perusahaan untuk menangani ketidakpastian lingkungan dan permasalahan yang berkaitan dengan sosial. Hal ini sebagai upaya untuk menghadapi lingkungan eksternalnya, seperti pihakpihak yang punya keterlibatan langsung maupun tidak langsung dengan perusahaan seperti karyawan, pelanggan, pemasok, pemegang saham, pemerintah maupun masyarakat (Gao et al., 2016). Perusahaan yang berpartisipasi dalam memberikan donasi dalam kegiatan corporate social responsibility mendapatkan manfaat yang potensial (Wu et al., 2018), citra serta reputasi perusahaan akan semakin meningkat, relasi yang semakin baik dengan pemerintahan dan publik, manfaat pajak serta meningkatkan efisiensi perusahaan (Hou et al., 2019). Tingginya kepedulian pada aspek lingkungan dan sosial mencerminkan hal yang baik bagi pelanggan potensial sehingga meningkatkan loyalitas para pelanggan (Lin et al., 2018). 
Faktor yang mendorong perusahaan memberikan donasi sebagai bentuk tanggung jawab sosialnya tentu dipengaruhi oleh keputusan yang diambil oleh pihak manajemen perusahaan. Upaya perusahaan dalam menjalin hubungan yang baik dengan para pemangku kepentingan yang dilakukan dengan memberikan donasi untuk kegiatan corporate social responsibility erat kaitannya dengan karakteristik anggota dewan direksi dan komisaris, baik itu berupa latar belakang pribadi maupun sosial (Cha \& Abebe, 2016). Karakteristik yang mampu mempengaruhi keputusan anggota dewan direksi dan komisaris untuk berkontribusi dalam memberikan donasi dalam kegiatan corporate social responsibility meliputi usia, jenis kelamin, pendidikan, lamanya bekerja serta total kompensasi (Wu et al., 2018). Namun pada penelitian ini akan secara spesifik membahas mengenai gender atau jenis kelamin dari dewan komisaris dan direksi. Gender yang menjadi fokus penelitian adalah pada jenis kelamin perempuan dan laki-laki pada anggota dewan. Tiga alasan yang menjadi dasar pentingnya penelitian tentang anggota dewan direksi dan komisaris perempuan berkaitan dengan keputusan perusahaan memberikan donasi dalam corporate social responsibility atau istilahnya corporate philanthropy meliputi: terdapat dorongan untuk berkembang pada bisnis yang bertanggung jawab terhadap lingkungan dan sosial yang melibatkan peran anggota dewan direksi dan komisaris, penelitian terkait donasi dalam kegiatan tanggung jawab sosial atau corporate philanthropy masih kurang mengeksplorasi tentang komposisi anggota dewan, yang terakhir adanya fakta bahwa posisi dewan perempuan masih belum proposional dibanding dewan laki-laki sehingga sangat perlu untuk meneliti mengenai peran dan kontribusi perempuan mengenai permasalahan lingkungan dan sosial (Cha \& Abebe, 2016).

Perempuan mempunyai keterlibatan yang lebih tinggi dalam melakukan donasi dalam kegiatan tanggung jawab sosial atau corporate philanthropy jika dibandingkan dengan laki-laki (Emrich \& Pierdzioch, 2015). Perusahaan yang mempunyai proporsi anggota perempuan memiliki keterlibatan lebih tinggi dalam melakukan donasi dalam melakukan tanggung jawab sosial atau corporate philanthropy (Cha \& Abebe, 2016). Keterlibatan yang lebih tinggi menunjukkan bahwa semakin baik pula kinerja para anggota dewan perempuan terkait keputusan perusahaan melakukan corporate philanthropy dengan memberikan donasi dalam kegiatan tanggung jawab sosial sesuai kepentingan Istakeholder (Lin et al., 2018). Keberadaan perempuan sebagai anggota dewan direksi dan komisaris mampu meningkatkan kontribusi dalam melakukan corporate philanthropy dengan memberikan donasi pada permasalahan lingkungan dan sosial bahkan dimasa kritis (Schwartz-Ziv, 2017). Hasil berbeda menyatakan keberadaan perempuan tidak berpengaruh signifikan terkait upaya perusahaan dalam melakukan tanggung jawab sosialnya (Alazzani et al., 2019).

Faktor lain yang menjadi pendorong untuk mempengaruhi perusahaan memberikan donasinya dalam kegiatan corporate social responsibility adalah jenis industri perusahaan. Jenis industri yang mempunyai risiko tinggi terhadap lingkungan mempunyai kepedulian yang lebih baik terkait lingkungan dan sosialnya (Badingatus Solikhah, 2016). Jenis industri yang berbeda mampu mempengaruhi kepedulian terhadap corporate social responsibility yang berbeda pula. Umumnya industri yang bergerak dibidang manufaktur mempunyai 
kepedulian yang tinggi dan lebih memperhatikan upaya yang dilakukan untuk melakukan tanggung sosial dan lingkungan dikarenakan dampak operasional yang dihasilkan (Susanto \& Joshua, 2019). Perusahhaan dalam industri energi, kimia serta pertambangan juga memunyai kontribusi yang lebih baik terkait tanggung jawab sosialnya dikarenakan mempunyai kepekaan yang tinggi terkait permasalahan lingkungan (Bhatia \& Makkar, 2020). Hasil berbeda menyatakn bahwa jenis industri tidak mempunyai pengaruh yang signifikan untuk mendorong perusahaan melakukan tanggung jawab sosialnya (Linda Pratiwi, 2019) dan (Muhammad Fajrul Novrizal, 2016).

Faktor selanjutnya yang juga mendorong perusahaan untuk melakukan tanggung jawab sosial adalah ukuran perusahaan. Ukuran perusahaan memiliki pengaruh positif terhadap tanggung jawab sosial yang dilakukan pihak perusahaan (Priyadi, 2016). Perusahaan yang memiliki ukuran besar menjadi sorotan publik terkait kinerjanya sehingga untuk menunjukkan citra yang baik perusahaan melakukan tanggung jawab sosialnya dengan lebih baik (Linda Pratiwi, 2019). Semakin besar ukuran perusahaan menunjukkan bahwa suatu perusahaan akan semakin mempunyai kepedulian yang tinggi terhadap permasalahan yang berkaitan dengan lingkungan (Badingatus Solikhah, 2016). Perusahaan semakin termotivasi untuk menunjukkan bahwa perusahaan yang mempunyai ukuran besar tidak hanya berorientasi pada profit saja tapi juga mempunyai kepedulian yang tinggi berkaitan dengan tanggung jawab sosial (Muhammad Fajrul Novrizal, 2016). Upaya yang dilakukan perusahaan ini juga bertujuan untuk membangun hubungan yang baik dengan pihak stakeholder agar perusahaan besar tesebut semakin dipercaya kualitas serta kinerjanya yang baik. Hasil berbeda menunjukkan ukuran perusahaan tidak memberikan jaminan bahwa perusahaan tersebut mempunyai kepedulian yang tinggi untuk melakukan tanggung jawab sosial (Agus Dwi Santoso, 2017) dan (Puti Tri Kartini, 2019).

Teori yang menjadi dasar dalam penelitian ini adalah Stakeholder theory dan feminist care ethics. Stakeholder theory menjelaskan bahwa dalam menjalankan bisnisnya suatu perusahaan tidak hanya bertujuan untuk mencari keuntungan saja. Perusahaan juga harus mampu melakukan tanggung jawab pada pihak stakeholder. Hal ini dikarenakan stakeholder mempunyai peran yang penting dalam suatu entitas bisnis, sehingga terjalinnya hubungan yang baik harus bisa dijaga. Upaya perusahaan untuk terus mempunyai hubungan yang positif dengan pihak stakeholder dengan melakukan salah satu bentuk tanggung jawab sosial yaitu dengan memberikan donasi sebagai bentuk corporate philanthropy (Gao et al., 2016). Perusahaan dengan dewan perempuan cenderung lebih menghargai kepentingan stakeholder dan meningkatkan donasinya (Lin et al., 2018) sehingga menciptakan kinerja ekonomi yang baik. Perusahaan yang memberikan kontribusi yang besar dalam kegiatan tanggung jawab sosial mampu memberikan promosi citra yang baik pada pihak stakeholder maupun pada publik secara luas sehingga menunjukkan bahwa perusahaan mempunyai citra dan kepedulian yang baik (Luo et al., 2017).

Feminist ethics theory memberikan penjelasan mengenai dalam menghadapi suatu pilihan moral terdapat perbedaan sikap yang ditunjukkan oleh gender atau jenis kelamin yang dimiliki. Pada perempuan menunjukkan 
bahwa terdapat kecenderungan untuk lebih altruistic dan perhatian ketika melakukan keputusan yang berkaitan dengan nilai moral. Perempuan mampu memahami nilai moralitas sebagai cara untuk menunjukkan rasa kepedulian serta upaya menghindari bahaya, sehingga saat melakukan pengambilan keputusan lebih menggunakan analisis situasional dan emosional. Sedangkan laki-laki dalam pengambilan keputusan berdasarkan alasan pikiran yang logis. Perempuan cenderung lebih sensitif secara etis dan mempunyai empati yang lebih tinggi dibandingkan laki-laki (Rao \& Tilt, 2015), karakteristik ini menjadikan perempuan dan laki-laki memiliki perbedaan moralitas ketika mengadopsi nilai-nilai kepemimpinan pada manajemen ( $\mathrm{Wu}$ et al., 2018). Perempuan yang cenderung lebih sensitif, menunjukkan tanggung jawab secara sosial, dan perilaku yang etis dalam kinerja perusahaan, menjadikannya mengarah pada efek yang positif terkait dengan upaya perusahaan untuk melakukan donaasi atau corporate philanthropy dan perilaku etis (Setó-Pamies, 2015) dan (Yasser et al., 2017).

Secara sistematis kerangka konseptual pada penelitian ditunjukkan pada Gambar 1, yaitu sebagai berikut.

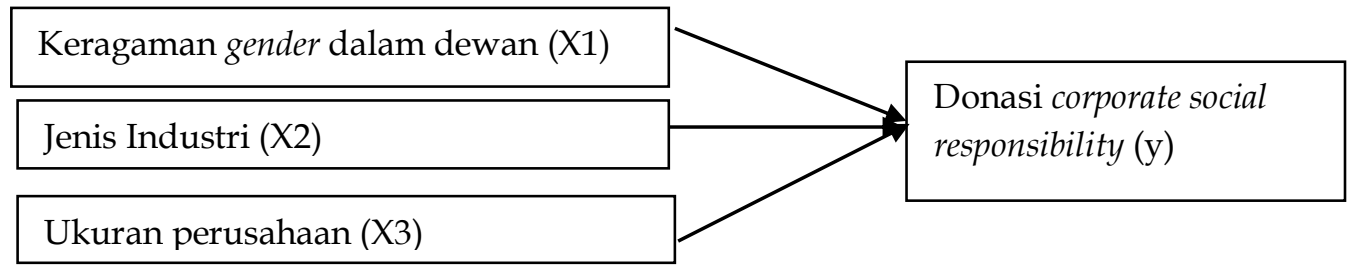

Sumber: Data Penelitian, 2020

\section{Gambar 1. Kerangka konseptual}

Anggota dewan komisaris dan direksi tentu memiliki perbedaan dalam menjalankan operasional perusahaan yang berpengaruh pada kinerjanya. Salah satu penyebabnya adalah perbedaan karakteristiknya secara spesifik yaitu perbedaan gender yang dimiliki. Kehadiran perempuan menunjukkan hasil yang positif dan menunjukkan perilaku yang lebih etis dibanding laki-laki, sehingga kehadiran perempuan mempunyai pengaruh yang postif terkait pengambilan keputusan pada masa yang akan datang (Lin et al., 2018). Keragaman gender dalam anggota dewan menunjukkan hubungan yang terkait dengan kinerja sosial perusahaan (Shamsul N. Abdullah, 2016). Adanya perempuan dalam anggota dewan memberikan pengaruh yang positif pada upaya perusahaan melakukan donasi dalam kegiatan corporate social responsibility dan akhirnya bisa meningkatkan reputasi perusahaan (Yasser et al., 2017). Kaitannya dengan stakeholder theory yang menunjukkan bahwa adanya perempuan dalam jajaran anggotan dewan direksi dan dewan komisaris mampu menjadi pendorong perusahaan untuk membangun sebuah hubungan yang baik dengan stakeholder. Tingkat kepedulian yang tinggi pada perempuan dalam dewan terkait dengan isu sosial maupun lingkungan yang terjadi membuat perempuan mampu melakukan corporate philanthropy atau donasi dalam kegaiatan corporate social responsibility jauh lebih baik dibandingkan dewan yang didominasi laki-laki. Anggota dewan perempuan mempunyai kepekaan terkait inisiatifnya dalam melakukan tanggung jawab sosial dan mampu memberikan perspektiff yang baik terkait permasalahan sosial dan lingkungan (Katmon et al., 2017). Teori 
kedua yang mendukung adanya peran penting perempuan dalam melakukan corporate philanthropy sebagai bentuk donasi yang diberikan dalam kegiatan corporate social responsibility yaitu feminist care ethics. Adanya feminist care ethics mendukung perempuan dalam jajaran anggota dewan direksi dan komisaris untuk berperan lebih baik dalam melakukan tanggung jawab sosial perusahaan (Wu et al., 2018). Hasil berbeda ditunjukkan terkait peran perempuan dalam dewan bila jumlahnya hanya satu maka tidak berpengaruh pada kontribusinya dalam melakukan tanggung jawab sosial (Alazzani et al., 2019). Sehingga hipotesisnya sebagai berikut.

$\mathrm{H}_{1}$ : Keberagaman gender dalam dewan berpengaruh terhadap donasi dalam corporate social responsibility.

Jenis industri yang mempunyai risiko lebih tinggi tentunya mempunyai kemampuan untuk melakukan tanggung jawab sosial lebih tinggi. Adanya variasi jenis industri pada tingkat philanthropy saat memberikan donasi dalam kegiatan corporate social responsibility hal ini dikarenakan beberapa industri lebih bersifat proaktif dibanding industri lain akibat sifat produknya serta profil pasarnya dan alasan yang kedua adalah beberapa industri lebih rentan menjadi sorotan dari publik akibat kegiatan operasional yang dilakukan (Cha \& Abebe, 2016). Pada Negara maju maupun Negara berkembang industri memiliki pengaruh yang signifikan terhadap upaya perusahaan melakukan kontribusi dalam melakukan tanggung jawab sosial (Bhatia \& Makkar, 2020). Faktor industri mempunyai pengaruh yang besar terhadap kinerja perusahaan dalam melakukan tanggung jawab sosialnya. Perusahaaan yang mempunyai kepekaan tinggi menjadi sorotan massyarakat terkait dampak yang ditimbulkan sehingga lebih peduli pada lingkungan san sosial (hasanah, 2020). Teori yang memperkuat dibuatnya hipotesis adalah stakeholder theory. Perusahaan yang melakukan tanggung jawab sosial merupakan bagian dari upaya untuk menjalin hubungan dengan dengan pihak stakeholder dan memberikan informasi untuk pengambilan keputusan (Rahmawati, 2019). Kegiatan operasional yang berbeda tentunya menghasilkan dampak yang berbeda pula, disini peran perusahaan untuk terus membangun hubungan dan komunikasi yang baik dengan pihak stakeholder dalam melakukan tanggung jawab sosialnya (LH, 2017). Namun hasil yang berbeda menunjukkan bahwa industri tidak berpengaruh signifikan terhadap tanggung jawab sosial yang dilakukan perusahaan (Linda Pratiwi, 2019) dan (Muhammad Fajrul Novrizal, 2016). Sehingga hipotesis kedua menyatakan bahwa.

$\mathrm{H}_{2}$ : Jenis industri berpengaruh terhadap donasi dalam corporate social responsibility.

Ukuran perusahaan merupakan variabel penting untuk menguji kemampuan perusahaan untuk melakukan tanggung jawab sosial. Hal ini dikarenakan terdapat perbedaan pada perusahaan besar dan kecil dalam melakukan tanggung jawab sosial. perusahaan besar mempunyai kecenderungan yang lebih tinggi untuk melakukan tanggung jawab sosial dengan lebih sukarela (Zhang et al., 2016). Perusahaan dengan ukuran yang semakin besar tentunya mempunyai kegiatan operasional yang lebih besar pula dan dapat menimbulkan dampak pada lingkungan maupun sosial dengan masyarakat sekitar (LH, 2017). Ukuran perusahaan juga menunjukkan besarnya aset milik perusahaan tersebut, 
sehingga perusahaan yang semakin besar tentunya menjadi sorotan pihak stakeholder (Priyadi, 2016). Teori yang menjadi dasar pengembangan hipotesis adalah stakeholder theory, hal ini dikarenakan pihak stakeholder akan terus memantau dan memberikan perhatian kepada perusahaan dengan ukuran besar terkait aktivitasnya. Pihak stakeholder tentunya tidak mengharapkan perusahaan mempunyai risiko yang membahayakan lingkungan maupun sosial dan upaya perusahaan untuk meyakinkan pihak stakeholder tentunya dengan memberikan kontribusi yang lebih banyak dalam melakukan tanggung jawab sosialnya (LH, 2017). Perusahaan yang lebih besar juga mendapatkan tekanan yang lebih besar untuk memberikan pertanggungjawabannya, sehingga dengan memberikan donasi dalam kegiatan corporate social responsibility membuat perusahaan semakin meningkatkan citranya dengan baik (Bhatia \& Makkar, 2020). Namun hasil lain menunjukkan bahwa ukuran perusahaan tidak mempunyai pengaruh terhadap kemampuan perusahaan untuk melakukan tanggung jawab sosial semakin tinggi (Puti Tri Kartini, 2019). Sehingga hipotesinya menyatakan bahwa.

$\mathrm{H}_{3}$ : Ukuran perusahaan berpengaruh terhadap donasi dalam corporate social responsibility.

\section{METODE PENELITIAN}

Jenis penelitian yang dilakukan adalah penelitian kuantitatif. Penelitian kuantitatif fokus pada pengujian hipotesis yang dilakukan atas dasar analisis data dengan prosedur statistik untuk mengetahui hubungan kausalitas pada variabel yang digunakan dalam penelitian (Sugiyono, 2012). Jenis data yang digunakan adalah data sekunder dari laporan tahunan, laporan berkelanjutan dan laporan corporate socil responsibility. Periode pengambilan sampel data adalah periode 2017-2018. Pengumpulan data menggunakan metode dokumentasi, yang dilakukan dengan cara mengumpulkan data dari website masing-masing perusahaan dan dari www.idx.co.id. Populasi penelitian mengunakan perusahaan dengan jenis industri pertambangan, manufaktur, energy, kimia, farmasi, food and beverage, jasa, perhotelan, perikanan, perkebunan, telekomunikasi, transportasi, serta kesehatan. Sampel penelitian ditentukan dengan menggunakan metode purposive sampling. Tujuannya adalah agar penelitian bisa lebih spesifik dan fokus sesuai dengan kriteria yang diperlukan. Kriteria yang digunakan meliputi: Perusahaan yang melakukan publikasi laporan corporate social responsibility, laporan tahunan, dan sustainability reporting pada periode 2017-2018, serta Perusahaan yang mencantumkan nilai atau jumlah total donasinya yang tercatat sebagai bentuk pertanggung jawaban sosial periode 2017-2018.

Variabel independen keragaman gender dalam dewan atau board gender diversity menjelaskan mengenai gambaran proporsi anggota dewan komisaris dan direksi. Jumlah dewan direksi dan komisaris perempuan dalam suatu perusahaan memberikan pengaruh yang signifikan terhadap kemampuan perusahaan untuk melakukan donasi dalam upaya tanggung jawab sosialnya (Cha \& Abebe, 2016). Pengukuran yang dilakukan seperti penelitian yang dilakukan (jia \& zhang 2012).

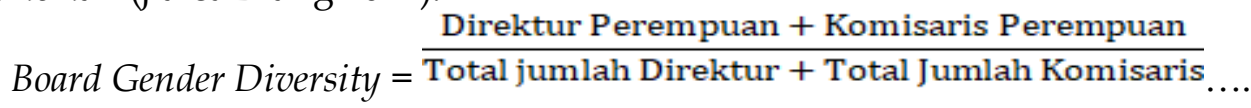


Variabel independen yang kedua adalah jenis industri. Jenis industri menunjukkan perbedaan dalam melakukan tanggung jawab sosial (Susanto \& Joshua, 2019). Pengukuran yang dilakukan untuk variabel jenis industri menggunakan variabel dummy yaitu dengan memberikan nilai 1 pada perusahaan yang termasuk dalam industri pertambangan, manufaktur, energi serta kimia. Sedangkan nilai 0 untuk perusahaan farmasi, food Ebeverage, jasa, perhotelan, perikanan, perkebunan, telekomunikasi serta transportasi.

Variabel independen yang ketiga adalah ukuran perusahaan. Ukuran perusahaan merupakan nilai maupun skala yang dipergunakan untuk bisa menentukan tingkatan besar dan kecilnya perusahaan. Ukuran perusahaan menjadi faktor yang penting untuk mengukur hubungan dengan tanggung jawab sosial perusahaan (Muhammad Fajrul Novrizal, 2016) dan Zhang et al., 2016). Pengukuran yang dilakukan untuk variabel ukuran perusahaan seperti penelitian yang dilakukan oleh (Zhang et al., 2016) yaitu.

Ukuran perusahaan $=$ Ln Total Aset

Variabel dependen dalam penelitian adalah donasi dalam kegiatan corporate social responsibility atau istilah lainnya menyebut dengan corporate philanthropy. donasi atau pemberian yang dilakukan perusahaan merupakan bentuk kontribusi yang dilakukan perusahaan sebagai upaya pertanggungjawaban sosial (Gao et al., 2016). Tidak semua perusahaan melaporkan dengan detail jumlah donasi yang diberikan dalam kegiatan corporate social responsibility dalam laporan tahunan maupun sustainability reporting padahal hal ini penting untuk dilaporkan sebagai bukti bahwa perusahaan tersebut memang benar telah melakukan tanggung jawabnya. Pengukuran yang digunakan untuk variabel ini sesuai penelitian (Gao et al., 2016) yaitu.

Donasi $=\log$ total donasi.

Teknik analisis data yang dilakukan untuk pengujian menggunakan regresi beganda. Uji statistik deskriptif bertujuan untuk memberikan gambaran mengenai standar deviasi, minimum, maksimum, serta nilai rata-rata (mean). Analisis terkait hasil uji statistik deskriptif digunakan untuk memberikan gambaran mengenai variabel dalam penelitian. Uji $t$ bertujuan untuk menguji pengaruh satu variabel independen terhadap variabel dependen dalam penelitian (Ghozali,2011). Uji t berfungsi untuk mengetahui tanda dari koefisien regresi variabel independen, sehingga bisa menentukan arah pengaruhnya. Uji F digunakan untuk mengetahui apakah variabel independen secara simultan berpengaruh terhadap variabel dependen. Pengujian multikolinieritas dilakukan untuk mengetahui hubungan linier antara variabel independen dalam model. Jika hasil pengujian menunjukkan adanya multikolinieritas maka terjadi kemungkinan menerima hipotesis yang salah. Jika nilai value inflation factor (VIF) $>100$ dan tolerance value $<0,10$ maka bisa diasumsikan terjadi multikolinieritas (Ghozali, 2013P:106).

Pengujian heteroskedasitas digunakan untuk memastikan data absolut residual tidak boleh memiliki korelasi dengan variabel independen dalam penelitian. Pengujian dilakukan dengan uji glejser. Apabila variabel independen mempengaruhi variabel dependen, maka absolut residual secara signifikan mengindikasikan adanya heteroskedasitas (Ghozali, 2013:143). Jika nilai signifikansi variabel independen $<0,05$ maka terjadi heteroskedasitas. Pengujian 
koefisien determinasi $\left(\mathrm{R}^{2}\right)$ bertujuan untuk mengukur kemampuan pengaruh variabel independen terhadap variabel dependen. Nilai koefisien determinasi $\left(\mathrm{R}^{2}\right)$ semakin tinggi mendekati nilai 1, maka hasil regresi tersebut baik. Hal ini menunjukkan bahwa variabel independen mampu menjelaskan variasi perubahan variabel dependen. Nilai koefisien determinasi $\left(\mathrm{R}^{2}\right)$ semakin kecil mendekati 0, maka variabel independen tidak mampu menjelaskan variasi perubahan variabel dependen.

Analisis regresi berganda bertujuan untuik menjelaskan hasil pengujian dari regresi yang dilakukan pada model penelitian. Analisis regresi memberikan gambaran mengenai nilai konstanta serta besarnya koefisien dari variabel penelitian. Nilai koefisien bisa digunakan untuk menjelaskan arah negative dan positif variabel independen terhadap variabel dependen. Persamaan model penelitian adalah sebagai berikut:

DONCSR $=\alpha+\beta_{1} B G D+\beta_{2} I N D+\beta 3 F S I Z E+\varepsilon$.

\section{HASIL DAN PEMBAHASAN}

Analisis deskriptif bertujuan untuk memberikan gambaran terkait variabel yang digunakan dalam penelitian.

Tabel 1. Hasil Uji Statistik Deskriptif

\begin{tabular}{llccc}
\hline No & Variabel & N & Mean & $\begin{array}{c}\text { Standar } \\
\text { Deviasi }\end{array}$ \\
\hline 1 & Donasi CSR / DONCSR(Y) & 197 & 9,4360 & 1,0831 \\
2 & Keragaman gender Dewan / BGD (X1) & 197 & 0,0996 & 0,1053 \\
3 & Jenis Industri / IND (X2) & 197 & 0,5939 & 0,4923 \\
4 & Ukuran perusahaan / FSIZE (X3) & 197 & 13,2253 & 7,6132 \\
\hline
\end{tabular}

Sumber: Data Penelitian, 2020

Berdasarkan jumlah data dalam penelitian yaitu sebanyak 197 data. Hasil pengujian deskriptif statistic menunjukkan bahwa variabel donasi CSR menunjukkan nilai mean sebesar 9,4360 dengan standar deviasi sebesar 1,0831. Variabel keragaman gender dewan nilai mean sebesar 0,0996 dengan standar deviasi sebesar 0,1053. Variabel Jenis industri nilai mean sebesar 0,5939 dengan standar deviasi sebesar 0,4923. Variabel ukuran perusahaan nilai mean sebesar 13,2253 dengan standar deviasi sebesar 7,6132.

Tabel 2. Hasil Uji t

\begin{tabular}{lcc}
\hline & $\mathrm{t}$ & $\mathrm{sig}$ \\
\hline constant & 43,695 & 0,000 \\
Keragaman gender Dewan / BGD (X1) & $-2,003$ & 0,047 \\
Jenis Industri / IND (X2) & 2,877 & 0,004 \\
Ukuran perusahaan / FSIZE (X3) & 0,730 & 0,466 \\
\hline
\end{tabular}

Sumber: Data Penelitian, 2020

Keragaman gender Dewan / BGD (X1) terhadap donasi CSR hasil regresi menunjukkan nilai signifikansi 0,047 < 0,05 maka hipotesis yang menyatakan bahwa keragaman berpengaruh terhadap corporate philanthropy diterima. Hasil pengujian menunjukkan bahwa $t_{\text {hitung }}<t_{\text {tabel }}$ dengan nilai $-2,003>1,65$. Menunjukkan bahwa variabel Keragaman gender Dewan / BGD (X1) mempunyai kontribusi terhadap variabel donasi CSR dan hubungannya berlawanan arah.

Jenis Industri / IND (X2) terhadap donasi CSR hasil regresinya adalah nilai signifikansi sebesar 0,004 < 0,05 maka hipotesis Jenis Industri / IND (X2) 
berpengaruh terhadap donasi CSR diterima. Nilai $t_{\text {hitung }}>t_{\text {tabel }}$ yaitu sebesar 2,877 $>1,65$, menunjukkan bahwa variabel Jenis Industri / IND (X2) mempunyai kontribusi terhadap variabel donasi CSR dan hubungannya searah.

Ukuran perusahaan / FSIZE (X3) terhadap donasi CSR hasil regresinya menunjukkan bahwa nilai signifikansi sebesar 0,466 < 0,05 maka hipotesis yang menyatakan bahwa Ukuran perusahaan / FSIZE (X3) berpengaruh terhadap donasi CSR ditolak. Nilai $t_{\text {hitung }}<t_{\text {tabel }}$ yaitu sebesar $0.730<1,65$, menunjukkan bahwa variabel Ukuran perusahaan / FSIZE (X3) tidak mempunyai kontribusi terhadap variabel donasi CSR dan hubungannya searah.

Tabel 3. Hasil Uji F

\begin{tabular}{lcc}
\hline model & F & Sig \\
\hline Regresi & 9,501 & 000 \\
\hline
\end{tabular}

Sumber : Data Penelitian, 2020

Pada hasil penelitian menunjukkan bahwa nilai f hitung sebesar 9,501. Nilai $F_{\text {hitung }}>F_{\text {tabel }}$ yaitu 9,501 $>3,04$ dan nilai signifikansi $0,00<0,05$ maka hipotesis diterima dan menunjukkan bahwa secara simultan atau bersama variabel keragaman gender dewan, jenis industri dan ukuran perusahaan berpengaruh signifikan terhadap variabel donasi CSR.

Tabel 4. Hasil Uji Multikolinearitas

\begin{tabular}{lcc}
\hline & Tolerance & VIF \\
\hline Keragaman gender Dewan / BGD (X1) & 0,984 & 1,016 \\
Jenis Industri / IND (X2) & 0,969 & 1,032 \\
Ukuran perusahaan / FSIZE (X3) & 0,987 & 1,014 \\
\hline
\end{tabular}

Sumber : Data Penelitian, 2020

Hasil pada pengujian menunjukkan bahwa Keragaman gender Dewan / BGD (X1) nilai VIF 1,016<100 dan untuk nilai tolerance value adalah $0,984>0,10$. Jenis Industri / IND (X2) nilai VIF 1,032<100 dan untuk nilai tolerance value adalah 0,969>0,10. Ukuran perusahaan / FSIZE (X3) nilai VIF 1,014<100 dan untuk nilai tolerance value adalah $0,987>0,10$ maka hal ini menjelaskan bahwa tidak terjadi multikolinearitas.

Tabel 5. Hasil Uji Heteroskedasitas

\begin{tabular}{lc}
\hline & Sig \\
\hline Keragaman gender Dewan / BGD (X1) & 0,353 \\
Jenis Industri / IND (X2) & 0,686 \\
Ukuran perusahaan / FSIZE (X3) & 0,889 \\
\hline
\end{tabular}

Sumber : Data Penelitian, 2020

Hasil pengujian menunjukkan bahwa nilai signifikansi variabel Keragaman gender Dewan / BGD (X1) yaitu 0,353 > 0,05. Pada variabel Jenis Industri / IND (X2) yaitu 0,686 > 0,05. Pada Ukuran perusahaan / FSIZE (X3) yaitu $0,686>0,05$. Sehingga dapat diasumsikan bahwa pada model regresi ketiga variabel independen dalam penelitian tidak terjadi heteroskedasitas karena ketiganya mempunyai nilai signifikansi lebih dari 0,05.

Tabel 6. Hasil Koefisien determinasi $\left(\mathbf{R}^{2}\right)$

\begin{tabular}{ccc}
\hline $\mathrm{R}$ & $\mathrm{R}$ square & Adjusted R Square \\
\hline 0,406 & 0,165 & 0,148 \\
\hline
\end{tabular}

Sumber : Data Penelitian, 2020 
Variabel independen dalam penelitian yaitu Keragaman gender Dewan / BGD (X1), Jenis Industri / IND (X2) dan Ukuran perusahaan / FSIZE (X3) mampu memprediksi variabel donasi CSR sebesar 16,5\% dan sisanya sebesar $83,5 \%$ diprediksi oleh variabel lain diluar penelitian.

Hasil analisis regresi berganda dari penelitian menunjukkan nilai DONCSR $=8,798-1,369$ BGD $+0,424 \mathrm{IND}+0,007$ FSIZE $+\varepsilon$. Konstanta (a) menunjukkan bahwa apabila semua variabel independen memiliki nilai nol (0) maka variabel independen nilainya sebesar 8,798. Pada variabel keragaman gender dewan $\left(\mathrm{X}_{1}\right)$ terhadap donasi CSR $(\mathrm{Y})$ nilai koefisien sebesar -1,369. Setiap kenaikan keragaman gender dewan satu satuan maka variabel donasi CSR akan naik sebesar -1,369 dengan asumsi bahwa variabel independen yang lain dari model regresi adalah tetap. Berdasarkan hasil uji $\mathrm{t}$ variabel keragaman gender dewan berpengaruh signifikan terhadap variabel donasi CSR sehingga hipotesis pertama diterima. Hal ini menunjukkan bahwa adanya keberagaman gender dalam dewan direksi dan komisaris dalam hal ini adanya perempuan menunjukkan kesadaran perusahaan untuk melakukan donasi CSR semakin tinggi. Keberadaan perempuan mendorong perusahaan untuk melakukan donasi CSR dengan baik. Upaya tersebut tentunya membuat citra perusahaa semakin baik.

Hasil ini didukung dengan adanya teori feminist ethics theory yang menyatakan bahwa dalam menghadapi pilihan moral perempuan menunjukkan perhatian yang lebih tinggi dan lebih altruistic. Perempuan juga menunjukkan kepedulian yang tinggi terhadap individu, kehidupan maupun orang lain saat membuat keputusan. Hasil ini juga didukung oleh teori stakeholder yang semakin menguatkan hasil penelitian. Keberadaan anggota dewan perempuan mampu melakukan evaluasi yang berkaitan dengan tanggungjawab sosial yang seharusnya dilakukan perusahaan sehingga corporate philanthropy atau donasi CSR bisa berjalan lebih efisien dan sesuai dengan kepentingan para stakeholdernya (Jia \& Zhang, 2012b). Hasil pengujian juga didukung oleh penelitian terdahulu Jia \& Zhang (2012a) Direktur perempuan lebih responsif terhadap bencana alam daripada pria, sehingga kehadiran para direktur perempuan bisa meningkatkan Corporate philanthropy. Adanya kehadiran perempuan secara positif terkait dengan adanya corporate philantrophy atau pemberian donasi CSR dan kepedulian terkait tanggung jawab sosial lebih tinggi (Bond et al., 2014), (Borghesi et al., 2014), dan (Kathleen Rupley, 2012).

Variabel jenis industri $\left(X_{2}\right)$ terhadap donasi CSR menunjukkan nilai koefisien sebesar 0,424 menunjukkan kenaikan jenis industri satu satuan maka variabel donasi CSR naik sebesar nilai tersebut dengan asumsi bahwa variabel independen yang lain dari model regresi adalah tetap. Berdasarkan hasil uji $t$ menunjukkan bahwa variabel jenis industri (X2) berpengaruh signifikan terhadap variabel donasi CSR (Y) yang artinya hipotesis diterima. Hal ini menunjukkan bahwa perusahaan yang kegiatan operasionalnya mempunyai risiko tinggi terhadap lingkungan memberikan perhatian lebih dengan cara melakukan donasi CSR dalam jumlah yang lebih besar. Pada penelitian ini perusahaan dalam industri pertambangan, manufaktur, energi serta kimia menunjukkan kontribusi yang besar saat melakukan donasi CSR. Hasil ini didukung adanya teori stakeholder yang mengasumsikan bahwa jenis industri 
mempunyai pengaruh terkait perusahaan melakukan tanggung jawab sosial yang merupakan bagian dari upaya untuk membangun hubungan baik dengan pihak stakeholder untuk mengurangi konflik (Christiawan, 2014), dan (Rahmawati, 2019). Hasil ini didukung oleh beberapa penelitian. Hasil yang menunjukkan bahwa jenis industri berpengaruh signifikan terhadap tanggung jawab sosial (LH, 2017) dan (Yunina, 2019). Perusahaan dengan jenis industri yang berdampak pada lingkungan mempunyai upaya tanggung jawab sosial yang lebih baik (Bhatia \& Makkar, 2020). Perusahaan yang produknya dikonsumsi publik menunjukkan bahwa mempunyai kemampuan melakukan tanggung jawab sosial lebih baik (Jianling Wang, 2013).

Variabel ukuran perusahaan $\left(X_{3}\right)$ terhadap donasi CSR menunjukkan nilai koefisien sebesar 0,007 yang atrtinya tiap kenaikan ukuran perusahaan satu satuan maka variabel donasi CSR akan naik sebesar nilai tersebut dengan asumsi variabel independen yang lain dari model regresi adalah tetap. Hasil uji $t$ menunjukkan bahwa variabel ukuran perusahaan (X3) tidak berpengaruh signifikan terhadap variabel donasi CSR (Y) yang menunjukkan bahwa hipotesisnya ditolak. Besar kecilnya perusahaan tidak menunjukkan adanya perbedan dalam melakukan donasi dalam CSR. Sesuai dengan beberapa penelitian yang menyatakan bahwa perusahaan besar pada kenyataannya belum tentu melakukan tanggung jawab dengan lebih baik. Ukuran perusahaan tidak berpengaruh signifkan terhadap besarnya tanggung jawab sosial yang dilakukan (Azwir Nasir, 2013). Besar dan kecilnya perusahaan serta banyaknya aset milik perusahaan tidak menunjukkan indikasi bahwa hal tersebut berpengaruh pada tanggung jawab sosial yang dilakukan (Effendi \& Sekarwigati, 2019). Tidak semua perusahaan yang besar dan perusahaan yang memliki tingkat aktiva tinggi fokus untuk menangani masalah lingkungan dan sosial masih ada perusahaan besar yang lebih berfokus pada pencapaian kinerja keuangannya saja (Salim, 2014).

\section{SIMPULAN}

Tanggung jawab sosial yang dilakukan perusahaan merupakan aspek penting yang harus dilakukan sebagai upaya untuk menjaga hubungan baik dengan masyarakat, stakeholder, maupun pemerintahan. Adanya penelitian ini bertujuan untuk menggali lebih dalam mengenai bentuk corporate social responsibility yang dilakukan perusahaan, sampai sejauh mana perusahaan mampu memberikan kontribusinya. Hal ini ditinjau dari besarnya donasi yang diberikan perusahaan yang dicantumkan dalam laporan tahunan perusahaan. Hal ini penting untuk diteliti karena perusahaan harus mampu memberikan informasi yang detail mengenai besarnya kontrbusi yang diberikan bukan hanya bentuk kegiatannya saja yang dilaporkan. Pada penelitian ini menunjukkan hasil bahwa keberagaman gender dewan mempu membuat perusahaan memberikan kontribusi yang baik. Peran perempuan dalam dewan menunjukkan hasil yang membuat perusahaan bisa memberikan donasi dalam upaya tanggung jawab sosialnya. Jenis perusahaan dalam penelitian ini yaitu pertambangan, manufaktur, energy dan kimia yang dikategorikan sebagai industri dengan risiko yang tinggi juga menunjukkan bahwa perusahaan tersebut mempunyai tanggung jawab yang tinggi dengan memberikan kontribusi yang tinggi saat 
melakukan donasi CSR. Sedangkan pada ukuran perusahaan tidak menunjukkan kontribusi yang tinggi dalam melakukan donasi CSR. Perusahaan besar ternyata tidak selalu mempunyai kepedulian yang tinggi pada permasalahan lingkungan dan sosial. Kelemahan dalam penelitian ini terjadi saat pengambilan data donasi CSR, hal ini dikarenakan tidak semua perusahaan bisa terbuka dalam melakukan disclosure terkait tanggung jawab sosial yang dilakukan. Penelitian selanjutnya bisa lebih mengeksplorasi terkait faktor yang mempengaruhi perusahaan memberikan donasi dalam kegiatan CSR.

\section{REFERENSI}

Abebe, M., \& Cha, W. (2018). The effect of firm strategic orientation on corporate philanthropic engagement. Management Decision, 56(3), 515-533. doi:10.1108/md-09-2016-0625

Agus Dwi Santoso, S. W. U. E. A. (2017). Pengaruh kepemilikan saham publik, ukuran perusahaan dan profitabilitas terhadap corporate social responsibility disclosure (studi pada perusahaan perbankan yang terdaftar di bei periode 2012-2015. The 9th FIPA: Forum Ilmiah Pendidikan Akuntansi - Universitas PGRI Madiun Vol. 5 No. 1 Hlmn. 836-853.

Alazzani, A., Wan-Hussin, W. N., \& Jones, M. (2019). Muslim CEO, women on boards and corporate responsibility reporting: some evidence from Malaysia. Journal of Islamic Accounting and Business Research, 10(2), 274-296. doi:10.1108/jiabr-01-2017-0002

Azwir Nasir, P. K. D. T. D. H. (2013). Pengaruh Kepemilikan Manajerial, Leverage, Profitabilitas, Ukuran, Dan Umur Perusahaan Terhadap Pengungkapan Informasi Pertanggungjawaban Sosial Perusahaan Pada Perusahaan Food And Beverage Yang Terdaftar Di Bei. Jurnal Ekonomi Volume 21, Nomor 4 Desember 2013.

Badingatus Solikhah, A. M. W. (2016). Pengaruh Liputan Media, Kepekaan Industri, Dan Struktur Tata Kelola Perusahaan Terhadap Kualitas Pengungkapan Lingkungan (The Effect Of Media Coverage, Industry Sensitivity And Corporate Governance Structure On Environmental Disclosure Quality). Jurnal Akuntansi dan Keuangan Indonesia,, Juni 2016, Vol. 13, (No. 1), hal 1 - 22.

Bhatia, A., \& Makkar, B. (2020). Stage of development of a country and CSR disclosure - the latent driving forces. International Journal of Law and Management, ahead-of-print(ahead-of-print). doi:10.1108/ijlma-03-20200068

Bond, M., Harrigan, N., \& Slaughter, P. (2014). Sex composition of corporate boards and corporate philanthropy. Voluntary Sector Review, 5(3), 361-380. doi:10.1332/204080514x14150982123190

Borghesi, R., Houston, J. F., \& Naranjo, A. (2014). Corporate socially responsible investments: CEO altruism, reputation, and shareholder interests. Journal of Corporate Finance, 26, 164-181. doi:10.1016/j.jcorpfin.2014.03.008

Cha, W., \& Abebe, M. A. (2016). Board of directors and industry determinants of corporate philanthropy. Leadership \& Organization Development Journal, 37(5), 672-688. doi:10.1108/lodj-09-2014-0189 
Christiawan, R. A. P. d. Y. J. (2014). Pengaruh Profatibilitas, Likuiditas, Dan Leverage Terhadap Pengungkapan Corporate Social Responsibility (Studi Pada Perusahaan-Perusahaan Yang Mendapat Penghargaan Isra Dan Listed (Go-Public) Di Bursa Efek Indonesia (Bei) 2010-2012). Business Accounting Review,", Vol. 2, (No. 1, 2014).

Effendi, B., \& Sekarwigati, M. (2019). Pengaruh Ukuran Perusahaan, Profitabilitas, dan Likuiditas terhadap Corporate Social Responsibility Disclosure. STATERA: Jurnal Akuntansi dan Keuangan, 1(1), 16-33. doi:10.33510/statera.2019.1.1.16-33

Emrich, E., \& Pierdzioch, C. (2015). Gender and generosity in charitable giving: empirical evidence for the German Red Cross. Applied Economics Letters, 22(13), 1041-1045. doi:10.1080/13504851.2014.997917

Gao, Y., Lin, Y. L., \& Yang, H. (2016). What's the value in it? Corporate giving under uncertainty. Asia Pacific Journal of Management, 34(1), 215-240. doi:10.1007/s10490-016-9478-8

Gardberg, N. A., Zyglidopoulos, S. C., Symeou, P. C., \& Schepers, D. H. (2017). The Impact of Corporate Philanthropy on Reputation for Corporate Social Performance. Business $\mathcal{E}$ Society, 58(6), 1177-1208. doi:10.1177/0007650317694856

Ghozali, Imam. 2011. "Aplikasi Analisis Multivariate Dengan Program SPSS". Semarang: Badan Penerbit Universitas Diponegoro.

Ghozali, Imam. 2013. Aplikasi Analisis Multivariate dengan Program IBM SPSS 21 Update PLS Regresi. Semarang: Badan Penerbit Universitas Diponegoro.

hasanah, k. t. k. t. a. (2020). Pengaruh kinerja lingkungan, sensitivitas industri, dan ukuran perusahaan terhadap pengungkapan corporate social responsibility di perusahaan manufaktur yang terdaftar di bursa efek indonesia. Jurnal KRISNA: Kumpulan Riset Akuntansi; Vol. 12, No. 1 Juli 2020, pp. 190-196.

Hou, D., Meng, Q., Zhang, K., \& Chan, K. C. (2019). Motives for corporate philanthropy propensity: Does short selling matter? International Review of Economics \& Finance, 63, 24-36. doi:10.1016/j.iref.2018.07.009

Houqe, M. N., van Zijl, T., Karim, A. K. M. W., \& George, T. S. (2019). The value relevance of corporate donations. Pacific-Basin Finance Journal, 101127. doi:10.1016/j.pacfin.2019.03.004

Jia, M., \& Zhang, Z. (2012a). Critical Mass of Women on BODs, Multiple Identities, and Corporate Philanthropic Disaster Response: Evidence from Privately Owned Chinese Firms. Journal of Business Ethics, 118(2), 303-317. doi:10.1007/s10551-012-1589-7

Jia, M., \& Zhang, Z. (2012b). Women on boards of directors and corporate philanthropic disaster response. China Journal of Accounting Research, 5(1), 83-99. doi:10.1016/j.cjar.2012.01.001

Jianling Wang, L. S., \& Shujie Yao. (2013). The Determinants Of Corporate Social Responsibility Disclosure: Evidence From China. The Journal of Applied Business Research, Volume 29(Number 6). 
Kathleen Rupley, D. B., \& Scott Marshall. (2012). Governance, Media and the Quality of Environmental Disclosure. Accounting Faculty Publications and Presentations, Journal Accounting Public Policy, 31 (6), 610-640.

Katmon, N., Mohamad, Z. Z., Norwani, N. M., \& Farooque, O. A. (2017). Comprehensive Board Diversity and Quality of Corporate Social Responsibility Disclosure: Evidence from an Emerging Market. Journal of Business Ethics, 157(2), 447-481. doi:10.1007/s10551-017-3672-6

LH, L. F. (2017). Pengaruh Tipe Industri, Ukuran Dan Pertumbuhan Perusahaanterhadap Corporate Social Responsibility Disclosure ( Studi Pada Sektor Pertambangan, Perbankan Dan Industri Semen). Jurnal Ilmiah Mahasiswa FEB, 5(2).

Lin, T.-L., Liu, H.-Y., Huang, C.-J., \& Chen, Y.-C. (2018). Ownership structure, board gender diversity and charitable donation. Corporate Governance: The international journal of business in society. doi:10.1108/cg-12-2016-0229

Linda Pratiwi, K. I. (2019). Analisis Pengaruh Tipe Industri, Ukuran Perusahaan, Leverage Dan Profitabilitas Terhadap Pengungkapan Corporate Social Responsibility (Csr) Pada Perusahaan Manufaktur Di Bursa Efek Indonesia Tahun 2012-2014. Surakarta Accounting Review (SAREV), Vol. 1 (No. 1 Juni 2019).

Luo, J.-h., Xiang, Y., \& Zhu, R. (2017). Military top executives and corporate philanthropy: Evidence from China. Asia Pacific Journal of Management, 34(3), 725-755. doi:10.1007/s10490-016-9499-3

Muhammad Fajrul Novrizal, M. F. (2016). Faktor-Faktor yang Mempengaruhi Pengungkapan Corporate Social Responbility (CSR) pada Perusahaan yang Terdaftar di Jakarta Islamic Index (JII) tahun 20122015 dengan Menggunakan Islamic Social Reporting (ISR) Index sebagai Tolok Ukur Jurnal Ilmiah Mahasiswa Ekonomi Akuntansi (JIMEKA), Vol. 1, (No. 2, (2016) ), Halaman 177-189.

Priyadi, E. R. M. P. (2016). Pengaruh profitabilitas, leverage dan ukuran perusahaan terhadap pengungkapan tanggung jawab sosial perusahaan Jurnal Ilmu dan Riset Akuntansi : Volume 5, Nomor 10, Oktober 2016 ISSN : 2460-0585 1.

Puti Tri Kartini, R. M., Wiwik Tiswiyanti. (2019). Pengaruh Return on Asset (ROA), Return on Equity (ROE) dan Ukuran Perusahaan Terhadap Corporate Social Responsibility Disclosure. Jurnal riset akuntansi dan keuangan, 7 (2), 2019, 343-366. doi:10.17509/jrak.v7i2.15636

Rahmawati, F. J. E. (2019). Pengaruh Media Exposure, Sensitivitas Industri, Kepemilikan Asing, Kepemilikan Publik dan Profitabilitas Terhadap Environmental Disclosure dan Dampaknya Terhadap Nilai Perusahaan. Reviu Akuntansi dan Bisnis Indonesia, Vol. 3 No. 1, Hlm: 50-66, Juli 2019.

Rao, K., \& Tilt, C. (2015). Board Composition and Corporate Social Responsibility: The Role of Diversity, Gender, Strategy and Decision Making. Journal of Business Ethics, 138(2), 327-347. doi:10.1007/s10551-0152613-5

Salim, Y. M. H. (2014). Pengaruh Ukuran Perusahaan, Kinerja Keuangan, Tipe Industri, Dan Financial Leverage Terhadap Pengungkapan Corporate Social Responsibility: Studi Empiris Pada Perusahaan Manufaktur Yang 
Terdaftar Di Bursa Efek Indonesia Tahun 2011--2013. Jurnal akuntansi, 2 (april), 181- 201.

Schwartz-Ziv, M. (2017). Gender and Board Activeness: The Role of a Critical Mass. Journal of Financial and Quantitative Analysis, 52(2), 751-780. doi:10.1017/s0022109017000059

Setó-Pamies, D. (2015). The Relationship between Women Directors and Corporate Social Responsibility. Corporate Social Responsibility and Environmental Management, 22(6), 334-345. doi:10.1002/csr.1349

Shamsul N. Abdullah, k. n. i. k. i. 1. n. (2016). Does having women on boards create value? The impact of societal perceptions and corporate governance in emerging markets. Strategic Management Journal Strat. Mgmt. J., 37: 466-476 (2016). doi:10.1002/smj

Sugiyono. 2012. Metode Penelitian Kuantitatif Kualitatif dan R\&D. Bandung: Alfabeta.

Susanto, Y. K., \& Joshua, D. (2019). Pengaruh Tata Kelola Perusahaan Dan Karakteristik Perusahaan Terhadap Pengungkapan Tanggung Jawab Sosial Perusahaan. EKUITAS (Jurnal Ekonomi dan Keuangan), 2(4), 572. doi:10.24034/j25485024.y2018.v2.i4.4036

Wu, C., Guang, H., Xu, J., \& Wang, S. (2018). The effects of female executives on corporate philanthropy in China. Corporate Social Responsibility and Environmental Management, 26(3), 628-643. doi:10.1002/csr.1708

Yasser, Q. R., Al Mamun, A., \& Ahmed, I. (2017). Corporate Social Responsibility and Gender Diversity: Insights from Asia Pacific. Corporate Social Responsibility and Environmental Management, 24(3), 210-221. doi:10.1002/csr.1400

Yunina, N. F. (2019). Pengaruh Karateristik Perusahaan, Struktur Kepemilikan, Dan Good Corporate Governance Terhadap Luas Pengungkapan Triple Bottom 'Line Pada Perusahaan Lq45 Yang Terdaftar Di Bei Tahun 20142016. JURNAL AKUNTANSI DAN KEUANGAN, Volume 7, (Nomor 1, Februari 2019), p. 1-10.

Zhang, J., Marquis, C., \& Qiao, K. (2016). Do Political Connections Buffer Firms from or Bind Firms to the Government? A Study of Corporate Charitable Donations of Chinese Firms. Organization Science, 27(5), 1307-1324. doi:10.1287/orsc.2016.1084 